\title{
The Epidemiology of Celiac Disease in the General Population and High-Risk Groups in Arab Countries: A Systematic Review
}

\author{
Ashraf El-Metwally ${ }^{D},{ }^{1}$ Paivi Toivola, ${ }^{2}$ Khalid AlAhmary, ${ }^{1}$ Salwa Bahkali, ${ }^{3}$ \\ Ali AlKhathaami ${ }^{1},{ }^{4}$ Munira K. AlSaqabi, ${ }^{5}$ Shatha A. Al Ammar, ${ }^{6}$ Munazza Jawed, \\ and Saleh M. Alosaimi ${ }^{8}$ \\ ${ }^{1}$ College of Public Health and Health Informatics, King Saud Bin Abdulaziz University for Health Sciences, Riyadh, Saudi Arabia \\ ${ }^{2}$ King Abdullah Specialist Children's Hospital, King Abdulaziz Medical City, Riyadh, Saudi Arabia \\ ${ }^{3}$ Princess Nourah Bint Abdulrahman University, King Abdullah Bin AbdulAziz University Hospital, Riyadh, Saudi Arabia \\ ${ }^{4}$ King Abdulaziz Medical City, National Guard Health Affairs, College of Medicine, King Saud Bin Abdulaziz University for \\ Health Sciences, Riyadh, Saudi Arabia \\ ${ }^{5}$ College of Medicine, King Saud Bin AbdulAziz University for Health Sciences, Riyadh, Saudi Arabia \\ ${ }^{6}$ King Abdullah Bin Abdulaziz University Hospital, Riyadh, Saudi Arabia \\ ${ }^{7}$ Dow University of Health Sciences, Karachi, Pakistan \\ ${ }^{8}$ King Abdulaziz Medical City, National Guard Health Affairs, King Saud Bin Abdulaziz University for Health Sciences, \\ Riyadh, Saudi Arabia
}

Correspondence should be addressed to Ashraf El-Metwally; elmetwally.ashraf@outlook.com

Received 15 January 2020; Revised 11 May 2020; Accepted 16 May 2020; Published 4 June 2020

Academic Editor: Jonathan Muraskas

Copyright (c) 2020 Ashraf El-Metwally et al. This is an open access article distributed under the Creative Commons Attribution License, which permits unrestricted use, distribution, and reproduction in any medium, provided the original work is properly cited.

Background and Aims. Celiac disease (CD) is possibly the most common autoimmune disorder, which may lead to dietary problems in the Arab region. This paper is aimed at exploring the epidemiology of the celiac disease in Arab countries, including its prevalence, associated risk factors, and clinical patterns. Methods. An extensive search of the literature was conducted from electronic databases such as PubMed, Embase, and Google Scholar. In total, 134 research papers were retrieved. We extracted studies published from January 1996 to December 2019. Our search was limited to studies published in English. Findings. The review included 35 studies with 22,340 participants from 12 countries and demonstrated a wide variation in the prevalence of CD. The highest prevalence among the general population (3.2\%) was reported in Saudi Arabia, and the lowest (0.1\%) was reported in Tunisia. Women demonstrated a higher prevalence of celiac disease relative to men. The peak age at diagnosis fell between 1 and 3 years and 9-10 years. Most studies focused on type 1 diabetes. Children with type 1 diabetes have a higher prevalence of CD (range from 5.5\% to 20\%), while the prevalence of CD in Down's syndrome patients was $1.1 \%$ and $10.7 \%$ in UAE and Saudi Arabia, respectively. Other autoimmune diseases associated with CD are thyroid disease and irritable bowel disease. The most widely recognized clinical presentation was an inability to flourish and poor weight gain, followed by short stature, abdominal pain, abdominal distension, bloating, and chronic diarrhea. Conclusion. The prevalence of the celiac disease in Arab countries varies with sex and age. However, we found that celiac disease presented similar clinical characteristics independent of the geographic region. Longitudinal population-based studies are needed to better identify the true burden and determinants of celiac disease.

\section{Introduction}

Celiac disease $(\mathrm{CD})$ is a chronic inflammatory disease of the upper small intestine triggered by gluten protein intolerance, which is prevalent in "genetically predisposed individuals." Gluten is the wheat grain protein richly consumed in Western countries with an average daily intake of 10 to 20 grams/person/day [1]. It is comprised of prolamin 
and glutelin proteins. Both proteins abundantly possess glutamine and proline residues, which defy gastrointestinal digestion and promote the deamination process through the tissue transglutaminase (tTG) enzyme [1, 2]. It may lead to mucosal inflammation and villous atrophy, thus causing malabsorption [2]. The classical manifestation of $\mathrm{CD}$ is often present with all related signs and symptoms of malabsorption. Moreover, patients also experience diarrhea, steatorrhea, and loss of weight or growth failure [3]. Meanwhile, in children, the classical characteristics are diarrhea, failure to thrive, muscle wasting, poor appetite, abdominal distension, and sometimes emotional distress and lethargy [3].

The European Society for Paediatric Gastroenterology, Hepatology, and Nutrition (ESPGHAN) suggested diagnostic criteria for CD. According to the guidelines, it depends upon the gluten-dependent symptoms, CD-specific antibody levels, HLA-DQ2 and/or HLA-DQ8, and histopathologic findings, which are villous atrophy and crypt hyperplasia, in a biopsy of the duodenum [4].

Some epidemiological studies demonstrate that the prevalence of celiac disease has been undervalued, affecting not just Europeans but also the population of Mediterranean countries, including those in the Middle East $[5,6]$, where its prevalence of celiac disease is quite similar to that of the Western states [7]. The incidence of celiac diseases in the Middle East is reported to be high both among at-risk groups and the general population. This is due to dietary habits such as excessive consumption of barley and wheat as well as due to a higher frequency of DR3-DQ2 haplotypes [8]. From a global perspective, the incidence of celiac disease differs from $1: 132$ in Switzerland to $1: 1000$ and $1: 2000$ in other European countries [9]. In the risk groups for celiac disease, a hereditary connection is present in first-degree relatives with a frequency of $1: 22$ and in relatives of a second degree with a frequency of $1: 39$ [10]. Celiac disease is also prevalent in the Nordic countries [11] with a frequency in the population, estimated by the results of serological screening of blood donors (in some cases supplemented with biopsy), of about $1 / 300$ of that in the rest of Europe (especially that of Ireland and Italy) and around 1/250 of some areas of the United States [12]. In some regions, the prevalence of the celiac disease is $1 / 100$. The disease develops in relatives of the first degree of relationship with a frequency of $10-20 \%$ [13]. The ratio of occurrence classified based on gender is $2: 1$ (females to males). Several studies have identified risk groups in which celiac disease is detected most often $[13,14]$. This group includes people suffering from other autoimmune and genetic diseases, including autoimmune thyroiditis, autoimmune liver disease, diabetes mellitus, Down's syndrome, and Turner syndrome, and relatives of celiac disease patients. The frequency of celiac disease in the risk groups can reach up to $10 \%$. Therefore, an in-depth examination of patients with these diseases is recommended.

Several studies have been conducted about celiac disease in Arab countries; however, no recent epidemiological systematic review exists. We believed that ethnicity and geographical differences might affect disease frequency. Therefore, we carried out a systematic review to find the epi- demiology of CD in the Arab countries, and this includes the prevalence, associated risk factors, and clinical features.

\section{Methods}

This study used a systematic review research approach. To locate primary studies relevant to our review, a systematic and comprehensive search of multiple electronic databases, such as PubMed, Embase, and Google Scholar, was performed, with each database searched individually. The keywords based on Medical Subject Headings (MeSH) such as celiac disease, Arab countries, Saudi Arabia, epidemiology, prevalence, and Middle Eastern countries were systematically applied line by line and replicated in every source database using Boolean operators: (celiac or coeliac) AND (Algeria or Bahrain or Egypt or Iraq or Jordan or Kuwait or Lebanon or Libya or Morocco or Mauritania or Oman or Palestine or Qatar or Saudi Arabia or Somalia or Sudan or Syria or Tunisia or United Arab Emirates or Yemen) AND (epidemiology or risk or burden or prevalence or incidence or impact or prognosis). Complete local journal searching and crossreferencing were undertaken by two reviewers who agreed on the final selection of the articles.

2.1. Inclusion and Exclusion Criteria. The inclusion criteria were original research studies published in peer-reviewed journals, mainly focusing on epidemiology, burden, prevalence, risk factors, incidence, or prognosis of celiac disease in Arab countries. Studies that utilized observational, retrospective, and prospective studies and were published in English between 1996 and 2019 were included. Studies that were published before 1996 focused on non-Arab populations, or enclosed case reports, case series, and quasiexperimental research designs were excluded from this review.

2.2. Study Selection. The titles/abstracts of the search outcomes were studied, and when the suitability of the articles was in question, the full-text articles were demanded and evaluated. Based on the exclusion and inclusion criteria, relevant full-text articles were assessed, screened, and reviewed by two researchers for inclusion. Any disagreements between authors were resolved through discussion with the third author. This ensured that only the articles relevant to the research questions were included. In total, 134 research papers were retrieved. Of these, 35 were deemed suitable for analysis and relevant for inclusion into our documented review by both reviewers.

2.3. Data Analysis. All analyses and reviews on literature were conducted based on the PRISMA "(Preferred Reporting Items for Systematic Reviews and Meta-Analyses) guidelines. Relevant extracted papers were synthesized systematically. The collected data was summarized through narrative with an overview of geographical location, study design, study settings, populations, sample sizes, and case definition. It was then followed by synthesis of the selected studies based on the outcome measures. Due to the heterogeneity of the presented data, a meta-analysis was not possible. Figure 1 represents the article screening and retrieval process. 


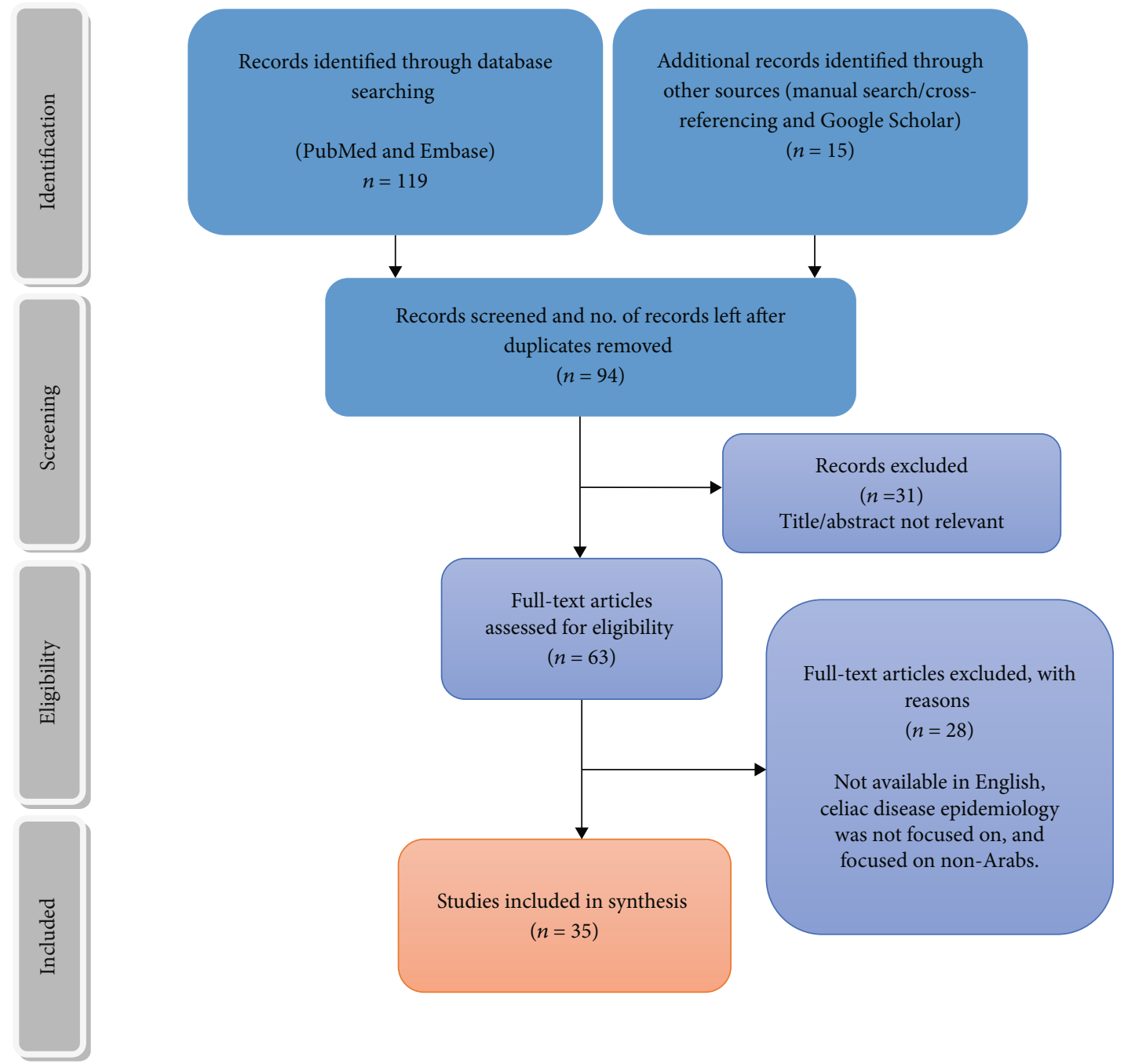

FIgURE 1: Retrieval of articles and screening process.

2.4. Quality Assessment. The quality of the studies included in this review was assessed using the Newcastle-Ottawa Scale (NOS) [15]. The scoring scale of the modified NOS ranges between 0 and 8: low-quality studies with NOS scores $0-2$, medium quality studies with NOS scores 3-5, and highquality studies with 6-8/9 NOS scores.

\section{Results}

Overall, 134 articles were reviewed and assessed for eligibility to meet our inclusion criteria. After individually reviewing each abstract against a prespecified inclusion criterion, 99 articles were excluded. This yielded 35 research articles, which focused primarily on the epidemiology of the celiac disease in Arab countries. The study selection process is summarized in Figure 1. We extracted articles from the period of 1996 to 2019. The studies included different research designs such as cross-sectional studies, prospective studies, casecontrol categorized under observational study design, and retrospective hospital-based studies with 22,340 participants from 12 Arab countries.
As seen in the following table, there were 35 published studies about celiac disease conducted in the Arab world. The national focus of these studies is divided in the following way: 17 were from Saudi Arabia, 1 from Algeria, 1 from Libya, 3 from Tunisia, 2 from Egypt, 2 from Oman, 2 from Jordan, 2 from the United Arab Emirates, 1 from Iraq, 1 from Kuwait, 1 from Qatar, 1 from Morocco, and 1 focused on the entire Middle East. The 22 studies focused on the prevalence, risk factors, and frequency of celiac disease among high-risk groups, and 9 focused on the prevalence of CD among the general population, while 4 of the 35 studies reported the clinical patterns and manifestation of CD.

3.1. Prevalence of Celiac Diseases among High-Risk Groups. It is clear from Table 1 that different researches have indicated that celiac disease presents an increased prevalence among several geographic regions. Most of the studies focused on type 1 diabetes. Children with type 1 diabetes have a higher prevalence of CD (range from 5.5\% to 20\%), while the prevalence of CD in Down's syndrome patients was $1.1 \%$ and $10.7 \%$ in UAE and Saudi Arabia, respectively. Other 
TABLE 1: The prevalence of celiac disease among high-risk groups.

\begin{tabular}{|c|c|c|c|c|c|c|c|}
\hline $\begin{array}{l}\text { S. } \\
\text { no. }\end{array}$ & $\begin{array}{l}\text { Authors } \\
\text { (year) }\end{array}$ & Country & Aims & $\begin{array}{c}\text { Study } \\
\text { design/population }\end{array}$ & $\begin{array}{c}\text { Diagnostic } \\
\text { criteria }\end{array}$ & Results & $\begin{array}{l}\text { NOS } \\
\text { score }\end{array}$ \\
\hline 1. & $\begin{array}{c}\text { Boudraa } \\
\text { et al. (1996) } \\
{[16]}\end{array}$ & $\begin{array}{l}\text { West } \\
\text { Algeria }\end{array}$ & $\begin{array}{l}\text { To assess the } \\
\text { prevalence of celiac } \\
\text { disease in insulin- } \\
\text { dependent diabetes } \\
\text { mellitus (IDDM) and } \\
\text { explore its presence in } \\
\text { their first-degree } \\
\text { relatives }\end{array}$ & $\begin{array}{l}\text { Prospective study } \\
\text { from } 1 \text { January } 1993 \\
\text { to } 31 \text { December } 1994 \\
116 \text { IDDM patients } \\
381 \text { first-degree } \\
\text { relatives of IDDM } \\
\text { patients }\end{array}$ & $\begin{array}{l}\text { Serological } \\
\text { markers, IgA and } \\
\text { IgG antigliadin } \\
\text { antibodies } \\
\text { (AGA), and IgA } \\
\text { antiendomysium } \\
\text { antibodies (EMA) } \\
\text { Jejunal biopsy of } \\
\text { symptomatic } \\
\text { patients }\end{array}$ & $\begin{array}{l}\text { Prevalence of CD in IDDM } \\
\text { patients was } 16 \% \text { to } 20 \% \text { (since } \\
\text { not all patients with positive } \\
\text { serological markers experienced } \\
\text { jejunal biopsy, the prevalence can } \\
\text { be considerably higher up to } \\
20 \% \text { ) } \\
\text { In } 1^{\text {st }} \text {-degree relatives, } 6.8 \% \\
\text { positive for one serological } \\
\text { marker, while } 3.4 \% \text { had villous } \\
\text { atrophy. }\end{array}$ & 6 \\
\hline 2. & $\begin{array}{c}\text { Al Attas } \\
(2002)[17]\end{array}$ & $\begin{array}{l}\text { Eastern } \\
\text { Saudi } \\
\text { Arabia }\end{array}$ & $\begin{array}{c}\text { To estimate CD } \\
\text { prevalence in clinically } \\
\text { suspicious celiac } \\
\text { disease patients and in } \\
\text { patients with disorders } \\
\text { considered to have an } \\
\text { association with CD, } \\
\text { such as autoimmune } \\
\text { diseases }\end{array}$ & $\begin{array}{c}\text { Hospital-based } \\
\text { study } \\
\text { Group } 1=145 \\
\text { patients (clinically } \\
\text { suspected) } \\
\text { Group } 2=80 \text { with } \\
\text { autoimmune } \\
\text { diseases } \\
\text { Group } 3=20 \\
\text { patients with IBD } \\
\text { Group } 4=100 \\
\text { heathy blood donors }\end{array}$ & $\begin{array}{l}\text { IgA-EMA and } \\
\text { intestinal biopsy } \\
\text { of confirmed } \\
\text { cases }\end{array}$ & $\begin{array}{c}\text { Group } 1=\text { EMA-positive } 7.6 \%, \text { bi } \\
\text { opsy conf irmed = } 4 \% \\
\text { group } 2=\text { EMA-positive } 2.5 \% \text { (all } \\
\text { have autoimmune thyroid } \\
\text { disease (AITD)), and groups } 3 \\
\text { and } 4=\text { no positive EMA. }\end{array}$ & 7 \\
\hline 3. & $\begin{array}{c}\text { Ashabani } \\
\text { et al. }(2003) \\
{[18]}\end{array}$ & Libya & $\begin{array}{l}\text { To investigate the CD- } \\
\text { related marker } \\
\text { occurrence in Libyan } \\
\text { children patients with } \\
\text { DM }\end{array}$ & $\begin{array}{l}\text { Cohort study } \\
\text { conducted on } 234 \\
\text { Libyan children with } \\
\text { DM (age range } 2 \text { to } \\
25 \text { years) and } 50 \\
\text { healthy children }\end{array}$ & $\begin{array}{l}\text { IgA and IgG, } \\
\text { AGA, anti-tTG, } \\
\text { anticalreticulin } \\
\text { antibodies, and } \\
\text { EMA }\end{array}$ & $\begin{array}{c}50(21.3 \%) \text { positive for IgA } \\
\text { and/or IgG-AGA, tTG, and } \\
\text { anticalreticulin antibodies } \\
19 \text { of these were EMA positive } \\
24 \text { had biopsy-proven CD } \\
\text { including EMA-negative patient } \\
\text { with IgA deficiency } \\
\text { Overall, CD prevalence found } \\
10.3 \%\end{array}$ & 6 \\
\hline 4. & $\begin{array}{c}\text { Al-Ashwal } \\
\text { et al. (2003) } \\
{[19]}\end{array}$ & $\begin{array}{l}\text { Saudi } \\
\text { Arabia }\end{array}$ & $\begin{array}{l}\text { To examine celiac } \\
\text { disease prevalence in } \\
\text { young Saudi patients } \\
\text { suffering from type I } \\
\text { diabetes mellitus at } \\
\text { "King Faisal Specialist } \\
\text { Hospital and Research } \\
\text { Centre, Riyadh" }\end{array}$ & $\begin{array}{l}\text { Hospital-based } \\
\text { research; } 123 \text { type } 1 \\
\text { diabetic patients }\end{array}$ & $\begin{array}{l}\text { Serum gliadin } \\
\text { immunoglobulin } \\
\text { (Ig) A and } \\
\text { reticulin IgA } \\
\text { antibody }\end{array}$ & $\begin{array}{c}\text { Serology positive } 10(8.1 \%) \\
6 \text { had jejunal biopsy and showed } \\
\text { villus atrophy; thus, prevalence } \\
\text { was } 4.9 \% \text {, based on biopsy results } \\
\text { and antibodies. }\end{array}$ & 7 \\
\hline 5. & $\begin{array}{l}\text { Nowier et al. } \\
(2009)[20]\end{array}$ & Egypt & $\begin{array}{c}\text { Celiac disease } \\
\text { prevalence among } \\
\text { Egyptians with type } 1 \\
\text { diabetes and the } \\
\text { association with } \\
\text { autoimmune thyroid } \\
\text { disease }\end{array}$ & $\begin{array}{l}\text { Case-control study } \\
\text { design where case } \\
\text { and control groups } \\
\text { were compared } \\
73 \text { type } 1 \mathrm{DM} \\
\text { patients }\end{array}$ & $\begin{array}{l}\text { Enzyme-linked } \\
\text { immunosorbent } \\
\text { assay (ELISA) } \\
\text { antibodies to tTG }\end{array}$ & $\begin{array}{l}\text { Prevalence of CD among type } 1 \\
\text { DM patients was } 5.48 \% \text { positive } \\
\text { anti-tTG antibodies } \\
\text { Anti-tTG antibody testing was } \\
\text { negative for patients with } \\
\text { autoimmune thyroid disease. }\end{array}$ & 8 \\
\hline 6. & $\begin{array}{l}\text { Al-Hussaini } \\
\text { et al. (2012) } \\
{[21]}\end{array}$ & $\begin{array}{l}\text { Middle } \\
\text { East }\end{array}$ & $\begin{array}{l}\text { To identify the } \\
\text { epidemiology of celiac } \\
\text { diseases among type } 1 \\
\text { diabetes in Middle } \\
\text { Eastern children }\end{array}$ & $\begin{array}{l}\text { Cross-sectional } \\
\text { study; } 106 \text { children } \\
\text { with type } 1 \text { diabetes }\end{array}$ & $\begin{array}{c}\text { IgA anti-tTG and } \\
\text { EMA }\end{array}$ & $\begin{array}{c}19(18 \%) \text { children showed } \\
\text { positive results of anti-tTG } \\
\text { and/or EMA } \\
12(11.3 \%) \text { children were found } \\
\text { to be CD positive by biopsy. }\end{array}$ & 6 \\
\hline 7. & $\begin{array}{l}\text { Saadah et al. } \\
(2012)[22]\end{array}$ & $\begin{array}{l}\text { Saudi } \\
\text { Arabia }\end{array}$ & $\begin{array}{l}\text { CD prevalence in } \\
\text { adolescent and } \\
\text { children patients with } \\
\text { type } 1 \mathrm{DM}\end{array}$ & $\begin{array}{c}\text { Retrospective } \\
\text { hospital record- } \\
\text { based study } \\
430 \text { diabetic children }\end{array}$ & $\begin{array}{l}\text { Anti-tTG } \\
\text { antibodies }\end{array}$ & $\begin{array}{c}91(21.2 \%) \text { positive for anti-tTG } \\
\text { antibody } \\
48(11.2 \%) \text { patients' biopsy }\end{array}$ & 3 \\
\hline
\end{tabular}


TABle 1: Continued.

\begin{tabular}{|c|c|c|c|c|c|c|c|}
\hline $\begin{array}{l}\text { S. } \\
\text { no. }\end{array}$ & $\begin{array}{l}\text { Authors } \\
\text { (year) }\end{array}$ & Country & Aims & $\begin{array}{c}\text { Study } \\
\text { design/population }\end{array}$ & $\begin{array}{l}\text { Diagnostic } \\
\text { criteria }\end{array}$ & Results & $\begin{array}{l}\text { NOS } \\
\text { score }\end{array}$ \\
\hline & & & & & & $\begin{array}{l}\text { confirmed CD (42 } \\
\text { asymptomatic). }\end{array}$ & \\
\hline 8. & $\begin{array}{l}\text { Al-Sinani } \\
\text { et al. }(2013) \\
{[23]}\end{array}$ & Oman & $\begin{array}{l}\text { Celiac disease } \\
\text { prevalence in Omani } \\
\text { children (type } 1 \\
\text { diabetics) }\end{array}$ & $\begin{array}{l}\text { A prospective cross- } \\
\text { sectional study } \\
103 \text { children with } \\
\text { type } 1 \text { diabetes }\end{array}$ & $\begin{array}{l}\text { Anti-tTG IgA, } \\
\text { EMA IgA, and } \\
\text { total IgA } \\
\text { Endoscopy and } \\
\text { biopsy }\end{array}$ & $\begin{array}{c}17 \%(N=14) \text { positive anti-tTG } \\
5.5 \%(n=5) \text { biopsy proven } \mathrm{CD} . \\
\text { Among these all } 5 \text { were also } \\
\text { positive for EMA. }\end{array}$ & 5 \\
\hline & & & & & & $\begin{array}{c}117(12.8 \%) \text { seropositive for CD. } \\
39(44.8 \%) \text { out of } 87 \text { biopsy } \\
\text { proven }\end{array}$ & \\
\hline 9. & $\begin{array}{l}\text { Farahid et al. } \\
(2014)[11]\end{array}$ & Jordan & $\begin{array}{l}\text { To estimate celiac } \\
\text { disease prevalence in } \\
\text { AIH patients in Jordan } \\
\text { and to determine } \\
\text { patients at higher } \\
\text { disease risk }\end{array}$ & $\begin{array}{l}\text { Cross-sectional } \\
\text { record-based review; } \\
914 \text { AIH patients } \\
\text { (108 males and } 806 \\
\text { females) aged } 20-82 \\
\text { years }\end{array}$ & $\begin{array}{l}\text { EMA IgA and IgG } \\
\text { Duodenal biopsy }\end{array}$ & $\begin{array}{l}\text { CD prevalence among patients } \\
\text { with AIH was estimated to be } \\
5.7 \% \text { in comparison to } \\
\text { seroprevalence of } 12.8 \% \\
\text { Higher association was found } \\
\text { between CD and age }>40 \text { years, } \\
\text { vitamin B12 deficiency, anemia, } \\
\text { and other autoimmune diseases } \\
\text { for example, Addison disease, } \\
\text { diabetes mellitus, and vitiligo. }\end{array}$ & 6 \\
\hline 10. & $\begin{array}{l}\text { Al-Hakami } \\
(2016)[24]\end{array}$ & $\begin{array}{l}\text { Saudi } \\
\text { Arabia }\end{array}$ & $\begin{array}{l}\text { To determine the } \\
\text { seroprevalence of } \\
\text { coexisting } \\
\text { autoantibodies among } \\
\text { patients with type } 1 \\
\text { diabetes and to look for } \\
\text { possible association } \\
\text { with glycemic control, } \\
\text { diabetes duration, and } \\
\text { diagnosis at Aseer } \\
\text { Central Hospital, Abha }\end{array}$ & $\begin{array}{l}\text { Cross-sectional } \\
\text { study } \\
202 \text { T1DM patients } \\
\text { were included in this } \\
\text { study }\end{array}$ & Anti-tTG, EMA & $\begin{array}{c}21(10.4 \%) \text { positive for both anti- } \\
\text { tTG and EMA } \\
\text { No significant association } \\
\text { between the age at T1DM } \\
\text { glycemic control, duration, and } \\
\text { diagnosis and the autoantibody } \\
\text { presence was observed. }\end{array}$ & 5 \\
\hline 11. & $\begin{array}{c}\text { Al-Ajlan } \\
(2016) \text { [25] }\end{array}$ & $\begin{array}{l}\text { Saudi } \\
\text { Arabia }\end{array}$ & $\begin{array}{c}\text { To examine the } \\
\text { implications and } \\
\text { prevalence of celiac } \\
\text { disease among Saudi } \\
\text { adults and comparing } \\
\text { it with diagnosed with } \\
\text { irritable bowel } \\
\text { syndrome at Al-Iman } \\
\text { General Hospital and } \\
\text { Prince Salman } \\
\text { Hospital, Riyadh }\end{array}$ & $\begin{array}{l}\text { Prospective case- } \\
\text { control study } \\
\text { Subjects aged 20-60 } \\
980 \text { adult patients } \\
\text { Among them, } 482 \\
\text { subjects were } \\
\text { controls and } 498 \\
\text { with IBS }\end{array}$ & $\begin{array}{l}\text { Anti-tTG and } \\
\text { EMA and biopsy }\end{array}$ & $\begin{array}{c}1.9 \% \text { CD in control group } \\
9.6 \% \text { in IBS group } \\
55 \text { out of } 980 \text { patients were found } \\
\text { to be positive for celiac disease. }\end{array}$ & 8 \\
\hline 12. & $\begin{array}{l}\text { Al-Hakami } \\
(2016)[26]\end{array}$ & $\begin{array}{l}\text { Saudi } \\
\text { Arabia }\end{array}$ & $\begin{array}{l}\text { To estimate the } \\
\text { prevalence of CD in } \\
\text { high-risk groups in } \\
\text { Aseer (southwest } \\
\text { region) and to } \\
\text { determine its } \\
\text { associations }\end{array}$ & $\begin{array}{l}\text { Laboratory records } \\
\text { (retrospective case- } \\
\quad \text { finding) } \\
\quad 315 \text { patients }\end{array}$ & $\begin{array}{l}\text { Anti-tTG and } \\
\text { EMA and biopsy }\end{array}$ & $\begin{array}{l}58(18.4 \%) \text { got a positive test for } \\
\text { at least one antibody marker } \\
17.5 \% \text { positive for anti-tTG } \\
15.6 \% \text { positive for EMA } \\
22 \text { out of } 40 \text { biopsies were } \\
\text { confirmed for CD } \\
\text { Type } 1 \text { DM was the most } \\
\text { common clinical illness related to } \\
\text { these markers with the } \\
\text { percentage } 47 \% \\
\text { However, gastrointestinal } \\
\text { presentations were observed to } \\
\text { be only } 11.5 \% \text {. }\end{array}$ & 4 \\
\hline 13. & & Iraq & $\begin{array}{l}\text { To evaluate silent CD } \\
\text { frequency in Iraqi }\end{array}$ & $\begin{array}{l}\text { Prospective cross- } \\
\text { sectional from }\end{array}$ & $\begin{array}{l}\text { IgA, anti-tTG- } \\
\text { IgA, anti-tTG- }\end{array}$ & $\begin{array}{c}11.2 \% \text { in Iraqi patients with type } \\
1 \mathrm{DM} .\end{array}$ & 6 \\
\hline
\end{tabular}


TABle 1: Continued.

\begin{tabular}{|c|c|c|c|c|c|c|c|}
\hline $\begin{array}{l}\text { S. } \\
\text { no. }\end{array}$ & $\begin{array}{l}\text { Authors } \\
\text { (year) }\end{array}$ & Country & Aims & $\begin{array}{c}\text { Study } \\
\text { design/population }\end{array}$ & $\begin{array}{l}\text { Diagnostic } \\
\text { criteria }\end{array}$ & Results & $\begin{array}{l}\text { NOS } \\
\text { score }\end{array}$ \\
\hline & $\begin{array}{l}\text { Mansour and } \\
\text { Najeeb } \\
(2011)[27]\end{array}$ & & $\begin{array}{l}\text { patients' sample with } \\
\text { type } 1 \text { diabetes mellitus }\end{array}$ & $\begin{array}{l}\text { November } 2008 \text { to } \\
\text { December } 2009 ; 62 \\
\text { patients with type } 1 \\
\text { diabetes mellitus } \\
\text { from age } 8 \text { to } 42\end{array}$ & $\begin{array}{l}\text { IgG, EMA-IgG, } \\
\text { and duodenal } \\
\text { biopsy }\end{array}$ & $\begin{array}{c}\text { 43.55\% had Marsh 0 } \\
\text { 16.1\% had Marsh I } \\
\text { 0\% had Marsh II } \\
\text { 3.2\% had Marsh IIIA } \\
\text { 4.83\% Marsh IIIB } \\
\text { 3.2\% Marsh IIIC } \\
\text { For diagnostic purposes, EMA } \\
\text { and tTG tests were found to be } \\
\text { useful. }\end{array}$ & \\
\hline 14. & $\begin{array}{l}\text { Fraser et al. } \\
(2003)[28]\end{array}$ & Oman & $\begin{array}{l}\text { To study the } \\
\text { association between } \\
\text { occult celiac disease } \\
\text { and iron deficiency } \\
\text { anemia in Omani } \\
\text { adults in Sultan } \\
\text { Qaboos University } \\
\text { Hospital, Muscat }\end{array}$ & $\begin{array}{l}\text { Hospital-based } \\
\text { study } \\
51 \text { patients }\end{array}$ & $\begin{array}{l}\text { IgA, anti-tTG- } \\
\text { IgA, anti-tTG- } \\
\text { IgG, EMA-IgG, } \\
\text { and duodenal } \\
\text { biopsy }\end{array}$ & $\begin{array}{c}\text { Mean Hb } 9 \text { with confirmed low } \\
\text { ferritin. } \\
2 \text { patients positive IgA-tTG and } \\
\text { IgA EMA and IgG tTG } \\
\text { One patient biopsy done and } \\
\text { showed villous atrophy. } \\
\text { Prevalence considered being } \\
\text { approximately } 1: 30 \text { in iron } \\
\text { deficiency patients and } 1 \text { in } 200- \\
300 \text { affected in the general } \\
\text { population. }\end{array}$ & 4 \\
\hline 15. & $\begin{array}{c}\text { Oujamaa } \\
\text { et al. }(2019) \\
{[29]}\end{array}$ & Morocco & $\begin{array}{l}\text { To examine the } \\
\text { prevalence of specific } \\
\text { autoantibodies to CD } \\
\text { in adult and pediatric } \\
\text { population with type } 1 \\
\text { diabetes }\end{array}$ & $\begin{array}{l}\text { Multicenter, cross- } \\
\text { sectional study } \\
\text { Study population } \\
\text { consists of } 276 \text { adults } \\
\text { and pediatric } \\
\text { diabetic patients }\end{array}$ & $\begin{array}{l}\text { Anti-tTG-IgA, } \\
\text { anti-tTG-IgG, } \\
\text { EMA, HLA- } \\
\text { DQ2/DQ8 typing, } \\
\text { and duodenal } \\
\text { biopsy }\end{array}$ & $\begin{array}{l}\text { Seroprevalence of CD in T1D } \\
\text { patients was } 9.1 \%(\mathrm{CI}=95 \%) \\
2 \text { cases had biopsy-proven CD. }\end{array}$ & 5 \\
\hline 16 & $\begin{array}{l}\text { Alyafei et al. } \\
(2018)[30]\end{array}$ & Qatar & $\begin{array}{l}\text { To determine the } \\
\text { prevalence of } \\
\text { autoantibodies in } \\
\text { diabetic patients in } \\
\text { Qatar }\end{array}$ & $\begin{array}{l}\text { Retrospective cross- } \\
\text { sectional study, } 490 \\
\text { pediatric patients } \\
\text { aged } 0.5 \text { - } 16 \text { years }\end{array}$ & $\begin{array}{l}\text { Anti-tTG IgA and } \\
\text { anti-tTG IgG } \\
\text { Biopsy }\end{array}$ & $\begin{array}{c}\text { In } 365 \text { T1DM, } 18(5 \%) \text { patients } \\
\text { have positive anti-tTG IgA and } \\
16(4.3 \%) \text { anti-tTG IgG } \\
\text { antibodies. } \\
\text { In } 46 \text { T2DM, anti-tTG IgA } \\
\text { antibodies were found in } 4 \\
\text { patients ( } 8.7 \%) \text {, whereas no anti- } \\
\text { tTG IgG antibodies detected in } \\
\text { any patient. } \\
\text { Mucosal biopsy proved celiac } \\
\text { disease in } 9 \text { out of } 12 \text { patients } \\
\text { (75\%) with positive ATT IgA and } \\
\text { IgG antibodies. }\end{array}$ & 4 \\
\hline 17 & $\begin{array}{l}\text { Odeh et al. } \\
(2019) \text { [31] }\end{array}$ & Jordan & $\begin{array}{l}\text { To determine the } \\
\text { prevalence of biopsy- } \\
\text { proven CD among } \\
\text { T1DM pediatric } \\
\text { patients }\end{array}$ & $\begin{array}{l}\text { Mixed prospective } \\
\text { and retrospective } \\
\text { study } \\
538 \text { children with } \\
\text { T1DM } \\
\text { Data collected from } \\
2012 \text { to } 2017\end{array}$ & $\begin{array}{l}\text { IgA-tTG and IgG- } \\
\text { tTG antibodies } \\
\text { Duodenal biopsy }\end{array}$ & $\begin{array}{c}\text { Prevalence of serology positive } \\
\text { CD was } 16.6 \% \text { while biopsy- } \\
\text { proven CD was } 9.1 \% .\end{array}$ & 5 \\
\hline 18 & $\begin{array}{c}\text { AlRuwaily } \\
\text { et al. (2017) } \\
\text { [32] }\end{array}$ & $\begin{array}{l}\text { Saudi } \\
\text { Arabia }\end{array}$ & $\begin{array}{l}\text { To determine the } \\
\text { prevalence of CD in } \\
\text { Down syndrome Saudi } \\
\text { patients }\end{array}$ & $\begin{array}{l}\text { Retrospective study, } \\
\text { files of } 91 \text { pediatric } \\
\text { patients for } \\
\text { serological markers } \\
\text { and biopsy results }\end{array}$ & $\begin{array}{l}\text { Antigliadin } \\
\text { antibody (AGA) } \\
\text { IgA and IgG, } \\
\text { EMA, IgA-tTG, } \\
\text { and IgG-tTG } \\
\text { antibodies }\end{array}$ & $\begin{array}{l}\text { (i) AGA-IgA found in } 32.14 \% \\
\text { (ii) AGA IgG in } 52.38 \% \\
\text { (iii) EMA tested positive in } \\
14.28 \% \text { and negative in } 69.04 \% \\
\text { (iv) Anti-tTG IgA was high in } \\
15.5 \% \\
\text { (v) Serum IgA normal level } \\
\text { found in } 43 \% \text { patients while low } \\
\text { in } 1.2 \% \text {. } \\
\text { Biopsy-confirmed cases of CD } \\
\text { was } 10.7 \% \text {. }\end{array}$ & 5 \\
\hline
\end{tabular}


TABLE 1: Continued.

\begin{tabular}{|c|c|c|c|c|c|c|c|}
\hline $\begin{array}{l}\text { S. } \\
\text { no. }\end{array}$ & $\begin{array}{l}\text { Authors } \\
\text { (year) }\end{array}$ & Country & Aims & $\begin{array}{c}\text { Study } \\
\text { design/population }\end{array}$ & $\begin{array}{l}\text { Diagnostic } \\
\text { criteria }\end{array}$ & Results & $\begin{array}{l}\text { NOS } \\
\text { score }\end{array}$ \\
\hline 19 & $\begin{array}{c}\text { Alghamdi } \\
\text { et al. (2018) } \\
{[33]}\end{array}$ & $\begin{array}{l}\text { Saudi } \\
\text { Arabia }\end{array}$ & $\begin{array}{l}\text { To determine the } \\
\text { prevalence of CD in } \\
\text { T1DM patient living in } \\
\text { Al-Baha region, Saudi } \\
\text { Arabia }\end{array}$ & $\begin{array}{l}\text { Retrospective } \\
\text { record-based study } \\
268 \text { T1DM patients } \\
\text { of age } 2-23 \text { years }\end{array}$ & $\begin{array}{l}\text { IgA-tTG and IgG- } \\
\text { tTG antibodies }\end{array}$ & $\begin{array}{c}\text { Prevalence of serology positive } \\
\text { cases of CD was } 7.1 \% . .\end{array}$ & 3 \\
\hline 20 & $\begin{array}{c}\text { Alshareef } \\
\text { et al. (2016) } \\
{[34]}\end{array}$ & $\begin{array}{l}\text { Saudi } \\
\text { Arabia }\end{array}$ & $\begin{array}{l}\text { To determine the } \\
\text { prevalence of CD in } \\
\text { T1DM patient of Saudi } \\
\text { Arabia }\end{array}$ & $\begin{array}{l}\text { Cross-sectional } \\
\text { study } \\
\text { 218 T1DM patients } \\
\text { with age } \geq 12 \text { years }\end{array}$ & $\begin{array}{c}\text { Anti-tTG } \\
\text { antibodies and } \\
\text { duodenal biopsy }\end{array}$ & $\begin{array}{l}\text { Raised anti-TTG levels found in } \\
7.3 \% \text { patients. } \\
\text { Duodenal biopsies were done in } \\
12 \text { patients which showed } \\
\text { (i) total villous atrophy } 3.7 \% \\
\text { (ii) subtotal villous atrophy } 0.8 \% \\
\text { Chronic duodenitis } 0.8 \%\end{array}$ & 4 \\
\hline 21 & $\begin{array}{c}\text { Al-Agha } \\
\text { et al. (2015) } \\
{[35]}\end{array}$ & $\begin{array}{l}\text { Saudi } \\
\text { Arabia }\end{array}$ & $\begin{array}{l}\text { To investigate the } \\
\text { coexistence of } \\
\text { autoimmune diseases } \\
\text { in T1DM patients }\end{array}$ & $\begin{array}{c}\text { Cross-sectional } \\
\text { study } \\
228 \text { patients with age } \\
1-18 \text { years }\end{array}$ & $\begin{array}{c}\text { Anti-tTG } \\
\text { antibodies and } \\
\text { jejunal biopsy }\end{array}$ & $\begin{array}{c}\text { Celiac disease was found in } \\
19.7 \% \text {. } \\
\text { CD was also significantly } \\
\text { associated with a high level of } \\
\text { HbA1C level }(\mathrm{OR}=1.016 ; 95 \% \\
\text { CI: } 0.884-1.166) .\end{array}$ & 5 \\
\hline 22 & $\begin{array}{c}\text { Abdulrazzaq } \\
\text { et al. (2018) } \\
{[36]}\end{array}$ & UAE & $\begin{array}{l}\text { To investigate the } \\
\text { presence of } \\
\text { autoimmune diseases } \\
\text { in Emirati children } \\
\text { with Down's syndrome }\end{array}$ & $\begin{array}{l}\text { Cross-sectional } \\
\text { study conducted on } \\
92 \text { Down's } \\
\text { syndrome patients }\end{array}$ & $\begin{array}{l}\text { Anti-tTG } \\
\text { antibodies }\end{array}$ & $\begin{array}{l}\text { Prevalence of CD in study } \\
\text { population was } 1.1 \% .\end{array}$ & 3 \\
\hline
\end{tabular}

Abbreviation: IgA-tTG: antitissue transglutaminase IgA; IgG-tTG: antitissue transglutaminase IgG; EMA: antiendomysium antibodies; AGA: antigliadin antibodies; NOS: Newcastle-Ottawa Scale.

autoimmune diseases associated with CD are thyroid disease and irritable bowel disease.

3.2. Prevalence of CD among General Population. The prevalence of $\mathrm{CD}$ in healthy adult populations was found to range from $0.14 \%$ to $3.2 \%$, the highest $(3.2 \%)$ prevalence being reported in Saudi Arabia and the lowest $(0.14 \%)$ in Tunisia (see Table 2). In healthy children, the estimated prevalence ranged from $0.6 \%$ to $1.5 \%$. Studies conducted in Saudi Arabia estimated the frequency of the disease to be $1: 250-100$. Approximately, the peak of diagnosis falls around the age of 1 to 3 years.

3.3. Clinical Pattern of Celiac Disease. Table 3 shows the clinical characteristics of laboratory-confirmed CD patients. The most widely recognized presentation was an inability to flourish and poor weight gain, followed by short stature, abdominal pain, abdominal distension, bloating, and chronic diarrhea.

\section{Discussion}

This review included 35 studies, showing a wide variation in the prevalence of $\mathrm{CD}$, ranging from $0.14 \%$ to $3.2 \%$. The highest prevalence among otherwise healthy individuals was reported in Saudi Arabia at 3.2\%, and the lowest was in Tunisia at $0.14 \%$. Gender distribution revealed a high occurrence in females. The peak age at diagnosis fell around the age of 13 years to 9-10 years. It was also found to be associated with type 1 diabetes in Saudi children in addition to thyroid dis- ease, Down syndrome, and irritable bowel disease. The most common symptoms were an inability to flourish, poor weight gain, short stature, chronic diarrhea, abdominal pain, gas, and bloating. Most of the studies used anti-tTG titers and EMA for their diagnosis. The role of family history was also highlighted in one study. Moreover, a gluten-free diet was found to improve laboratory parameters. However, noncompliance for this was also picked up by one of the studies.

Several studies have indicated that CD is occurring with increasing prevalence in several geographic regions, particularly in the regions of European origin, indicating that it is generally a lifelong disorder [48]. It usually affects one in a hundred among the general population, being more prevalent in the Middle East and North Africa [13]. The literature demonstrated that the CD prevalence rates were $1 \%$ for the United States and Europe and were similar in Argentina and Australia [13]. Prevalence in North Africa has been reported as $0.79 \%$ in Libya, $0.6 \%$ in Tunisia, and $0.53 \%$ in Egypt. A regional study on the Greater Middle East showed a prevalence rate of $0.88 \%$ in Iran, while it was $0.6 \%$ in Turkey. Studies have shown prevalence in India to be $0.7 \%$ [49], whereas in Germany, it was $0.3 \%, 0.9 \%$ in Northern Ireland, $1.2 \%$ in Italy, and 2\% in Finland [50]. However, in Saudi Arabia, it was between $2.1 \%$ and $8.5 \%$ [12], and not much statistical data were found on the frequency of $\mathrm{CD}$ due to the complexity of diagnosis, not only in adults but also in children.

Many of the studies included in this review concluded that CD occurred more frequently in females and particularly affected children more than adults. Likewise, its adult and 
TABLE 2: The prevalence of celiac disease among general population.

\begin{tabular}{|c|c|c|c|c|c|c|c|}
\hline $\begin{array}{l}\text { S. } \\
\text { no. }\end{array}$ & $\begin{array}{l}\text { Authors } \\
\text { (year) }\end{array}$ & Country & Aims & Study design/population & Diagnostic criteria & Results & $\begin{array}{l}\text { NOS } \\
\text { score }\end{array}$ \\
\hline 1. & $\begin{array}{l}\text { Bdioui } \\
\text { et al. } \\
(2006)[8]\end{array}$ & Tunisia & $\begin{array}{c}\text { To determine CD } \\
\text { prevalence among } \\
\text { Tunisian healthy blood } \\
\text { donors }\end{array}$ & $\begin{array}{l}\text { Prospective study; total } \\
1418,1090 \text { men and } 328 \\
\text { women }\end{array}$ & $\begin{array}{l}\text { IgA-EMA, anti-tTG, } \\
\text { and biopsy }\end{array}$ & $\begin{array}{c}\text { Prevalence of CD was } \\
\text { about } 1 / 700 \text { among } \\
\text { blood donors } \\
3 \text { positives for IgA } \\
\text { EMA, where } 2 \text { were } \\
\text { positive for anti-tTG } \\
\text { and also showed villous } \\
\text { atrophy }\end{array}$ & 5 \\
\hline 2. & $\begin{array}{l}\text { Hariz } \\
\text { et al. } \\
(2007) \\
{[37]}\end{array}$ & Tunisia & $\begin{array}{l}\text { To determine CD } \\
\text { prevalence among } \\
\text { Tunisian children and to } \\
\text { describe the clinical profile } \\
\text { of the screened patients }\end{array}$ & $\begin{array}{l}\text { Mass screening study; } 6286 \\
\text { children }\end{array}$ & $\begin{array}{l}\text { IgA-tTG, IgA-AE, } \\
\text { and biopsy }\end{array}$ & $\begin{array}{c}139 \text { positives for IgA- } \\
\text { tTG } \\
40 \text { positives for IgA-AE } \\
28 \text { had positive for both } \\
\text { (IgA-tTG, IgA-AE); } \\
\text { biopsy-proven CD } \\
\text { found in } 26 \\
\text { participants } \\
79 \text { had positive test for } \\
\text { only IgA-tTG; among } \\
\text { them, biopsy was } \\
\text { normal } \\
\text { Estimated prevalence } \\
\text { in school children } \\
1 / 157 .\end{array}$ & 5 \\
\hline 3. & $\begin{array}{c}\text { Khayyat } \\
(2012) \\
{[38]}\end{array}$ & $\begin{array}{l}\text { Western } \\
\text { region of } \\
\text { Saudi } \\
\text { Arabia }\end{array}$ & $\begin{array}{c}\text { Gluten sensitivity } \\
\text { prevalence in healthy Saudi } \\
\text { adults at "King Faisal } \\
\text { Specialist Hospital \& } \\
\text { Research Centre in Jeddah, } \\
\text { Saudi Arabia" }\end{array}$ & $\begin{array}{l}\text { Prospective pilot research } \\
\text { for Saudi attendees (in } \\
\text { blood donation center); } \\
204 \text { individuals ( } 122 \text { males } \\
\text { and } 82 \text { females) }\end{array}$ & $\begin{array}{l}\text { Anti-tTG IgA and } \\
\text { IgA level }\end{array}$ & $\begin{array}{l}3(1.5 \%) \text { people tested } \\
\text { positive for IgA TTG } \\
\text { showing normal IgA } \\
\text { level. }\end{array}$ & 4 \\
\hline 4. & $\begin{array}{l}\text { Aljebreen } \\
\text { et al. } \\
(2013) \\
{[39]}\end{array}$ & $\begin{array}{l}\text { Saudi } \\
\text { Arabia }\end{array}$ & $\begin{array}{c}\text { To recognize the } \\
\text { seroprevalence of } \mathrm{CD} \\
\text { among healthy adolescents } \\
\text { in Saudi Arabia }\end{array}$ & $\begin{array}{l}\text { Quantitative research by } \\
\text { randomly selecting } 10 \text { th- } \\
\text { to } 12 \text { th-grade students } \\
\text { from } 3 \text { distinct Saudi } \\
\text { regions, including Al- } \\
\text { Qaseem, Madinah, and } \\
\text { Aseer } \\
1167 \text { students }\end{array}$ & $\begin{array}{c}\text { EMA and IGA by } \\
\text { indirect } \\
\text { immunofluorescence }\end{array}$ & $\begin{array}{c}2.2 \% \text { ( } 26 \text { students) } \\
\text { showed a positive anti- } \\
\text { EMA test } \\
\text { The prevalence was } \\
\text { highest in the Al- } \\
\text { Qaseem region }(3.2 \%) \\
\text { However, the lowest } \\
\text { prevalence was found } \\
\text { in Madinah }(1.8 \%) \text {. }\end{array}$ & 6 \\
\hline 5. & $\begin{array}{l}\text { Al- } \\
\text { Hussaini } \\
\text { et al. } \\
(2017) \\
{[14]}\end{array}$ & $\begin{array}{l}\text { Saudi } \\
\text { Arabia }\end{array}$ & $\begin{array}{l}\text { To determine celiac disease } \\
(\mathrm{CD}) \text { prevalence and } \\
\text { illustrate the iceberg of } \\
\text { celiac disease among Saudi } \\
\text { pediatric population in } \\
\text { Riyadh }\end{array}$ & $\begin{array}{c}\text { Prospective cross-sectional } \\
\text { study } \\
7930 \text { students }\end{array}$ & $\begin{array}{l}\text { Anti-tTG IgA and } \\
\text { EMA-IgA and } \\
\text { biopsy }\end{array}$ & $\begin{array}{c}221(2.8 \%) \text { students } \\
\text { with positive TTG-IgA, } \\
\text { CD diagnosed in } 119 \\
\text { cases. } \\
\text { High CD prevalence } \\
\text { among Saudi children } \\
\text { was estimated to be } \\
1.5 \% .\end{array}$ & 5 \\
\hline 6. & $\begin{array}{c}\text { Al } \\
\text { Hatlani } \\
(2015) \\
{[40]}\end{array}$ & $\begin{array}{l}\text { Saudi } \\
\text { Arabia }\end{array}$ & $\begin{array}{l}\text { To determine the } \\
\text { prevalence of CD among } \\
\text { symptom-free children } \\
\text { from the military campus } \\
\text { (public school) of National } \\
\text { Guard in the Eastern } \\
\text { Province, Saudi Arabia }\end{array}$ & $\begin{array}{l}\text { Cross-sectional study } \\
1141 \text { students }\end{array}$ & $\begin{array}{l}\text { Anti-tTG-IgA and } \\
\text { IgG antibodies and } \\
\text { intestinal biopsy }\end{array}$ & $\begin{array}{c}32(3 \%) \text { IgA-tTG } \\
\text { positive } \\
\text { An intestinal biopsy } \\
\text { was also undertaken in } \\
10 \text { of them } \\
1 \% \text { biopsy-confirmed } \\
\text { prevalence. }\end{array}$ & 5 \\
\hline 7. & $\begin{array}{l}\text { Abu- } \\
\text { Zekry } \\
\text { et al. }\end{array}$ & Egypt & $\begin{array}{c}\text { To examine celiac disease } \\
\text { frequency in Egyptian } \\
\text { children }\end{array}$ & $\begin{array}{l}\text { Prospective cross-sectional } \\
\text { study } \\
\text { Group A: } 1500 \text { general } \\
\text { pediatric population }\end{array}$ & $\begin{array}{c}\text { Anti-tTG, IgA EMA, } \\
\text { total IgA, IgG anti- } \\
\text { tTG } \\
\text { Small bowel biopsy }\end{array}$ & $\begin{array}{c}\text { CD diagnosis was made } \\
\text { in } 2 \text { groups of patients: } \\
\text { A and B } \\
\text { Group A: } 8 \text { children }\end{array}$ & 7 \\
\hline
\end{tabular}


TABLE 2: Continued.

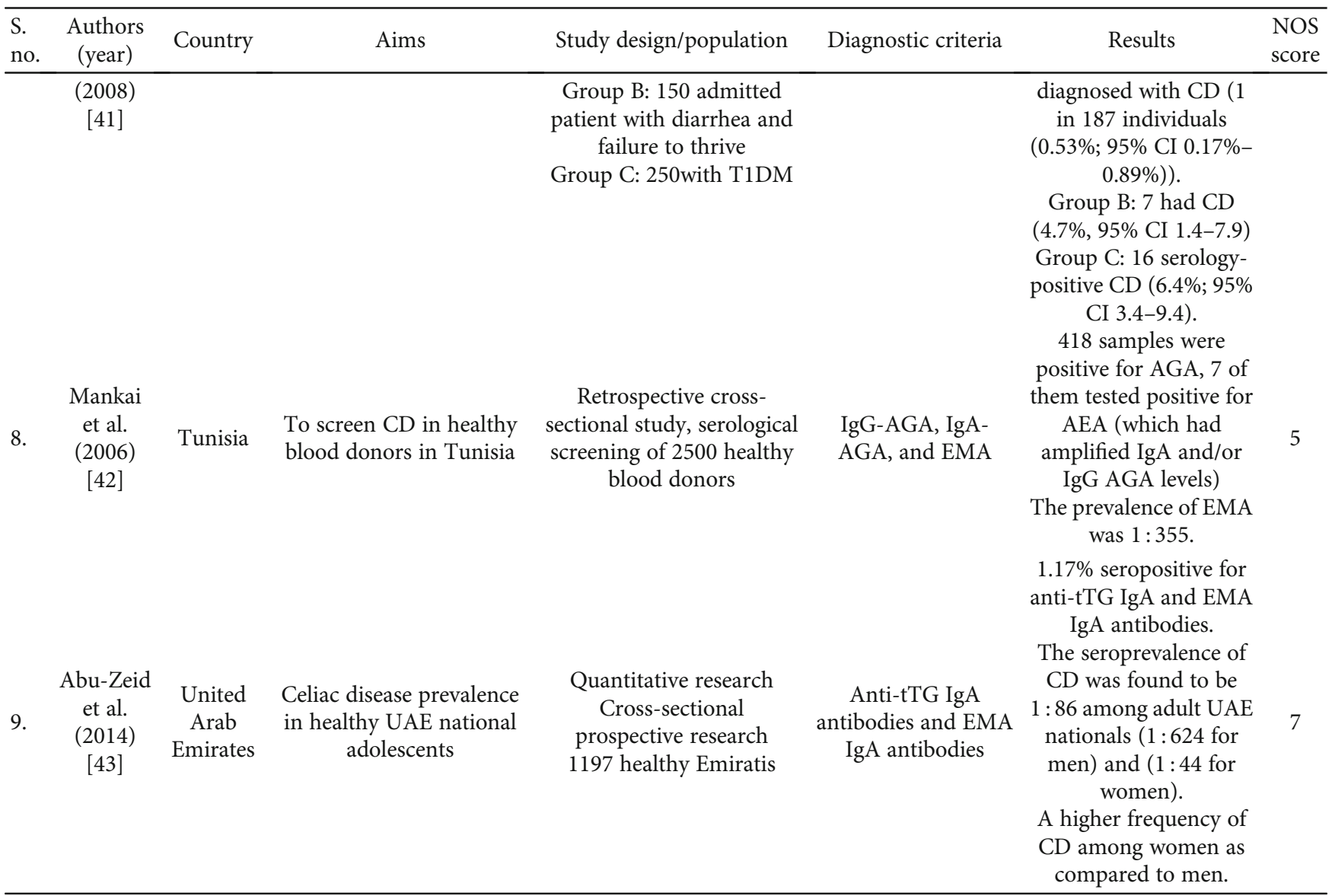

Abbreviation: IgA-tTG: antitissue transglutaminase IgA; IgG-tTG: antitissue transglutaminase IgG; EMA: antiendomysium antibodies; AGA: antigliadin antibodies; NOS: Newcastle-Ottawa Scale.

childhood occurrence in Sweden was between $1: 285$ and 1 : 77 [51], while it was $1: 230$ and $1: 106$ in Italian schoolaged kids [52]. Similar trends were also found in nonEuropean peoples such as Australia [53, 54], Argentina [54], Brazil [55], and New Zealand [56]. CD is a female predominant disease having a female to male ratio of $2: 1$ or $3: 1$ [57], which was congruent with the findings of this review. Ciacci et al. [58] established that women were diagnosed with $\mathrm{CD}$ at an early age, suffered more symptoms, had lower body mass index according to their age, and had severe anemia. According to Jane Anderson, up to $70 \%$ of individuals currently diagnosed with $\mathrm{CD}$ are female. This can be explained by two factors. Firstly, more women than men have it, and secondly, women seek medical care more often than males and hence get diagnosed more frequently if they have developed CD.

Despite its increasing prevalence, the diagnosis rate is low. This could be due to poor disease awareness as well as limited diagnostic facilities in these countries. It can sometimes occur as an asymptomatic condition, yet the common gastrointestinal presentations in children include failure to thrive, chronic diarrhea, abdominal distention, and a malabsorptive picture including anorexia, vomiting, and constipation [59]. These symptoms were in line with those evaluated by the majority of the studies where the diagnosis was made only based on the clinical picture and laboratory parameters. Some studies in our review also highlighted the coexistence of CD with other metabolic conditions. Previously published data also supported this comorbidity pattern. From a study, $6 \%$ of type 1 diabetes patients while $12 \%$ of those with Down syndrome had CD in United States [60]. Along with many other conditions, autoimmune thyroiditis [61] and irritable bowel disease were associated with CD [62].

Most of the studies used anti-tTG titers and EMA for CD diagnosis while one study also showed that the patient underwent endoscopy if any one of the listed tests were positive. Moreover, the anti-tTG was shown to have high specificity and sensitivity in diagnosing $C D$, specifically in type 1 diabetic children. On a similar note, testing serum levels of anti-tTG was acknowledged as the first choice for CD screening, displaying approximately $98 \%$ sensitivity and up to $96 \%$ specificity [59]. Improvement of the condition after excluding foods based on gluten products showed improvement in both laboratory indicators and symptoms of the patients. This treatment was also found effective by many other studies $[5,63]$.

The research review and analysis of this article contributes towards understanding the epidemiology and occurrence of CD in Saudi Arabia as well as other neighboring Middle Eastern and Gulf countries, providing a recent 
TABLE 3: Clinical characteristics in clinically and laboratory CD-confirmed population.

\begin{tabular}{|c|c|c|c|c|c|c|c|}
\hline $\begin{array}{l}\text { S. } \\
\text { no. }\end{array}$ & $\begin{array}{l}\text { Authors } \\
\text { (year) }\end{array}$ & Country & Aims & $\begin{array}{c}\text { Study } \\
\text { design/population }\end{array}$ & $\begin{array}{l}\text { Diagnostic } \\
\text { criteria }\end{array}$ & Case definition & $\begin{array}{l}\text { NOS } \\
\text { score }\end{array}$ \\
\hline 1 & $\begin{array}{l}\text { Wafa'a } \\
\text { Al- } \\
\text { Qabandi } \\
\text { et al. } \\
(2015) \\
{[44]}\end{array}$ & Kuwait & $\begin{array}{l}\text { To share the experience of } \\
\text { dealing with Kuwaiti children } \\
\text { suffering from celiac disease }\end{array}$ & $\begin{array}{l}\text { Retrospective } \\
\text { research } \\
47 \text { patients of CD } \\
\text { serology and } \\
\text { biopsy proven } \\
\text { (symptomatic: } 25, \\
\text { screened: } 22 \text { ) } \\
\text { Age range from } 7 \\
\text { to } 189 \text { months }\end{array}$ & $\begin{array}{l}\text { EMA, } \\
\text { AGA-IgA, } \\
\text { AGA-IgG, } \\
\text { and anti- } \\
\text { tTG }\end{array}$ & $\begin{array}{c}66 \% \text { females, } 34 \% \text { males, } 85 \% \text { EMA } \\
\text { positive, } 79 \% \text { AGA-IgA positive, and } \\
77 \% \text { AGA-IgG positive. } \\
19 \text { have T1D, } 2 \text { have Down's syndrome, } \\
1 \text { has both T1D and Down's syndrome, } \\
3 \text { have hypothyroidism, and } 1 \text { juvenile } \\
\text { has idiopathic arthritis } \\
9 \% \text { had celiac disease family history. }\end{array}$ & 6 \\
\hline 2 & $\begin{array}{c}\text { Saadah } \\
(2011) \\
{[45]}\end{array}$ & $\begin{array}{l}\text { Saudi } \\
\text { Arabia }\end{array}$ & $\begin{array}{l}\text { To identify the clinical pattern } \\
\text { of celiac disease prevalence }\end{array}$ & $\begin{array}{l}\text { Retrospective, } \\
\text { hospital-based } \\
\text { research }\end{array}$ & $\begin{array}{l}\text { Anti-tTG, } \\
\text { IgA, IgG } \\
\text { antibodies } \\
\text { and biopsy } \\
\text { proven }\end{array}$ & $\begin{array}{l}80 \text { children were diagnosed with celiac } \\
\text { disease (age range of } 0.5-18 \text { years) } \\
39(49 \%) \text { individuals showed } \\
\text { conventional symptoms of } \\
\text { malabsorption, while } 41 \text { ( } 51 \%) \text { were } \\
\text { found to be at high risk of developing } \\
\text { CD. } \\
73(91 \%)=\text { positive anti-tTG antibodies } \\
18(23 \%)=\text { positive IgG antibodies } \\
46(58 \%)=\text { positive IgA antibodies } \\
11 \text { out of } 65 \text { individuals showed } \\
\text { disturbed liver function tests. }\end{array}$ & 5 \\
\hline 3 & $\begin{array}{l}\text { Sarkhy } \\
\text { et al. } \\
(2015) \\
{[46]}\end{array}$ & $\begin{array}{l}\text { Saudi } \\
\text { Arabia }\end{array}$ & $\begin{array}{l}\text { To address clinical } \\
\text { characteristics of celiac disease } \\
\text { among Saudi children as well as } \\
\text { to examine the adherence rate } \\
\text { to gluten-free diet along with its } \\
\text { determinant factors }\end{array}$ & $\begin{array}{l}\text { Cross-sectional } \\
\text { study } \\
113 \text { children; } \\
\text { median age } 9.9 \\
\text { years }\end{array}$ & $\begin{array}{l}\text { Biopsy- } \\
\text { confirmed } \\
\text { cases }\end{array}$ & $\begin{array}{c}92 \% \text { of the patients were symptomatic } \\
\text { while } 8 \% \text { were asymptomatic. } \\
\text { Out of total, } 62 \text { of the children were } \\
\text { females. } \\
\text { The most commonly presenting } \\
\text { symptoms include poor weight gain } \\
\text { (54\%), chronic abdominal pain } \\
\text { (59.3\%), abdominal distention, gases, } \\
\text { bloating (46.1\%), and chronic diarrhea } \\
\text { (41.6\%). } \\
\text { Shorter duration since the diagnosis } \\
\text { and younger age at diagnosis were } \\
\text { interrelated with an improved } \\
\text { adherence rate. }\end{array}$ & 7 \\
\hline 4 & $\begin{array}{l}\text { Saeed } \\
\text { et al. } \\
(2017) \\
{[47]}\end{array}$ & $\begin{array}{l}\text { Saudi } \\
\text { Arabia }\end{array}$ & $\begin{array}{l}\text { To characterize the clinical } \\
\text { presentations and diagnosis in } \\
\text { children under the age of } 18 \\
\text { with celiac disease at a private } \\
\text { tertiary care health care center } \\
\text { in Riyadh }\end{array}$ & $\begin{array}{l}\text { Retrospective } \\
\text { study } \\
59 \text { children }\end{array}$ & $\begin{array}{c}\text { IgA-tTG } \\
\text { and IgG- } \\
\text { tTG } \\
\text { antibodies } \\
\text { and biopsy }\end{array}$ & $\begin{array}{c}50.8 \% \text { males } \\
\text { Median age } 8 \text { years } \\
\text { Mean duration of symptoms before } \\
\text { diagnosis } 2.3 \text { years }( \pm 1.5) \text {. } \\
\text { Classical disease was merely observed } \\
\text { in } 30.5 \% \text {, while } 69.5 \% \text { had either } \\
\text { nonclassical presentations or belonged } \\
\text { to high-risk groups for celiac disease } \\
\text { 91.5\% positive for IgA-tTG antibodies } \\
81.3 \% \text { positive for IgG-tTG } \\
52 \text { had Marsh grade III lesion. }\end{array}$ & 5 \\
\hline
\end{tabular}

Abbreviation: IgA-tTG: antitissue transglutaminase IgA; IgG-tTG: antitissue transglutaminase IgG; EMA: antiendomysium antibodies; AGA: antigliadin antibodies; NOS: Newcastle-Ottawa Scale.

comprehensive overview of the topic. Variation in statistics between the studies can also be attributed to different methodologies and sensitivities of diagnostic tools. There were certain limitations to this review. First, Arabic papers were not included, yet most of the research conducted in Arab countries is published in English anyways. Another important limitation lies in the fact that cross-sectional data cannot be used to infer causality. Another major drawback is that we could not conduct a meta-analysis due to the heterogeneity of data.

\section{Conclusion}

With increasing prevalence, $\mathrm{CD}$ is becoming a major public health concern; thus, investigating its epidemiology and 
clinical features is of great importance. It is now well known that gluten is a precipitating factor, and the research being conducted at present is adding to the understanding of other components of this condition. Awareness of the diversity of presenting symptoms has alerted health professionals to the possible diagnosis of celiac disease. Globally, many patients with celiac disease, including in Saudi Arabia and Gulf countries, remain undiagnosed, which may lead to the development of innovations in screening programs. A growing body of evidence reveals that there is an amplified possibility of celiac disease epidemics soon, especially in the Arab countries that practice gluten-rich dietary patterns. Since many of the cases remain underdiagnosed, the concerned authorities should endeavor to raise the responsiveness of celiac disease. There is a pressing need for research in the future to classify the exact prevalence of the celiac disease.

5.1. Implications. Although only $1 \%$ of the overall general population has $\mathrm{CD}$, evidence proposed that only around $10 \%$ to $15 \%$ of this population (children and adults) have been accordingly diagnosed and treated [64]. Hence, early CD diagnosis is crucial, as it might prevent complications. For this to happen, awareness is the key. Emphasis should be on effective communication between the patient and the physician to minimize the disease burden by screening for high-risk individuals. Additionally, periodic follow-up care of such patients is an essential element of effective longterm management of $\mathrm{CD}$. There is a definite need for public health involvement by raising attentiveness towards $\mathrm{CD}$ and related dietary habits as well as early screening programs. Future studies in the Arab world should be further aimed at investigating the clinical features of celiac disease and shedding more light on its associated risk factors, preventive measures, early diagnosis, and appropriate treatment modalities. Longitudinal population-based studies are needed in the future to better identify and respond to the burden and risk factors of celiac disease in Arab countries.

\section{Conflicts of Interest}

The authors declare that they have no competing interests.

\section{Acknowledgments}

We would like to thank Miss Laila Mohamed Ghoneim from the American University of Cairo for the proofreading and English language editing that greatly improved the manuscript.

\section{References}

[1] I. S. Cohen, A. S. Day, and R. Shaoul, "Gluten in celiac diseasemore or less?," Rambam Maimonides Medical Journal, vol. 10, no. 1, article e0007, 2019.

[2] A. Assa and Y. Frenkel-Nir, "Anthropometric measures and prevalence trends in adolescents with coeliac disease: a population based study," Archives of Disease in Childhood, vol. 102, no. 2, pp. 139-144, 2017.
[3] J. F. Ludvigsson, D. A. Leffler, J. C. Bai et al., "The Oslo definitions for coeliac disease and related terms," Gut, vol. 62, no. 1, pp. 43-52, 2013.

[4] S. Husby, S. Koletzko, I. Korponay-Szabo et al., "European Society for Pediatric Gastroenterology, Hepatology, and Nutrition guidelines for the diagnosis of coeliac disease," Journal of Pediatric Gastroenterology and Nutrition, vol. 54, no. 1, pp. 136-160, 2012.

[5] K. Barada, A. Bitar, M. A.-R. Mokadem, J. G. Hashash, and P. Green, "Celiac disease in Middle Eastern and North African countries: a new burden?," World Journal of Gastroenterology, vol. 16, no. 12, pp. 1449-1457, 2010.

[6] J. Kang, A. Kang, A. Green, K. Gwee, and K. Ho, "Systematic review: worldwide variation in the frequency of coeliac disease and changes over time," Alimentary Pharmacology \& Therapeutics, vol. 38, no. 3, pp. 226-245, 2013.

[7] A. Fasano, I. Berti, T. Gerarduzzi et al., "Prevalence of celiac disease in at-risk and not-at-risk groups in the United States: a large multicenter study," Archives of Internal Medicine, vol. 163, no. 3, pp. 286-292, 2003.

[8] F. Bdioui, N. Sakly, M. Hassine, and H. Saffar, "Prevalence of celiac disease in Tunisian blood donors," Gastroentérologie clinique et biologique, vol. 30, no. 1, pp. 33-36, 2006.

[9] A. J. Irvine, W. D. Chey, and A. C. Ford, "Screening for celiac disease in irritable bowel syndrome: an updated systematic review and meta-analysis," The American Journal Of Gastroenterology, vol. 112, no. 1, pp. 65-76, 2017.

[10] A. Hamzeh, P. Nair, N. Al-Khaja, and A. M. Al, “Association of HLA-DQA1 and -DQB1 alleles with type I diabetes in Arabs: a meta-analyses," Tissue Antigens, vol. 86, no. 1, pp. 21-27, 2015.

[11] O. Farahid, N. Khawaja, M. Shennak, A. Batieha, M. El Khateeb, and K. Ajlouni, "Prevalence of coeliac disease among adult patients with autoimmune hypothyroidism in Jordan," Eastern Mediterranean Health Journal, vol. 20, no. 1, pp. 5155, 2014.

[12] P. Singh, S. Arora, A. Singh, T. A. Strand, and G. K. Makharia, "Prevalence of celiac disease in Asia: a systematic review and meta-analysis," Journal of Gastroenterology and Hepatology, vol. 31, no. 6, pp. 1095-1101, 2016.

[13] C. Catassi, "New celiac icebergs are spotted, other are slowly emerging," Journal of Pediatric Gastroenterology and Nutrition, vol. 65, no. 6, pp. 601-602, 2017.

[14] A. Al-Hussaini, R. Troncone, M. Khormi et al., "Mass screening for celiac disease among school-aged children: toward exploring celiac iceberg in Saudi Arabia," Journal of Pediatric Gastroenterology and Nutrition, vol. 65, no. 6, pp. 646-651, 2017.

[15] J. Peterson, V. Welch, M. Losos, and P. J. Tugwell, The Newcastle-Ottawa Scale (NOS) for Assessing the Quality of Nonrandomised Studies in Meta-Analyses, Ottawa Hospital Research Institute, Ottawa, Canada, 2011.

[16] G. Boudraa, W. Hachelaf, M. Benbouabdellah, M. Belkadi, F. Benmansour, and M. Touhami, "Prevalence of coeliac disease in diabetic children and their first-degree relatives in West Algeria: screening with serological markers," Acta Paediatrica, vol. 85, no. s412, pp. 58-60, 1996.

[17] R. A. Al Attas, "How common is celiac disease in Eastern Saudi Arabia," Annals of Saudi Medicine, vol. 22, no. 5-6, pp. 315319, 2002.

[18] A. Ashabani, U. Abushofa, S. Abusrewill, M. Abdelazez, L. Tučková, and H. Tlaskalová-Hogenová, “The prevalence of 
coeliac disease in Libyan children with type 1 diabetes mellitus," Diabetes/Metabolism Research and Reviews, vol. 19, no. 1, pp. 69-75, 2003.

[19] A. A. Al-Ashwal, S. M. Shabib, N. A. Sakati, and N. A. Attia, "Prevalence and characteristics of celiac disease in type I diabetes mellitus in Saudi Arabia," Saudi Medical Journal, vol. 24, no. 10, pp. 1113-1115, 2003.

[20] S. R. Nowier, N. S. Eldeen, M. M. Farid, H. Rasol, and S. M. Mekhemer, "Prevalence of celiac disease among type 1 diabetic Egyptian patients and the association with autoimmune thyroid disease," Bratislavské Lekárske Listy, vol. 110, no. 4, pp. 258-262, 2009.

[21] A. Al-Hussaini, N. Sulaiman, M. Al-Zahrani, A. Alenizi, and I. El Haj, "High prevalence of celiac disease among Saudi children with type 1 diabetes: a prospective cross-sectional study," BMC Gastroenterology, vol. 12, no. 1, p. 180, 2012.

[22] O. I. Saadah, A. E. Al-Agha, H. M. Al Nahdi et al., "Prevalence of celiac disease in children with type 1 diabetes mellitus screened by anti-tissue transglutaminase antibody from Western Saudi Arabia," Saudi Medical Journal, vol. 33, no. 5, pp. 541-546, 2012.

[23] S. Al-Sinani, S. W. Sharef, S. Al-Yaarubi et al., "Prevalence of celiac disease in Omani children with type 1 diabetes mellitus: a cross sectional study," Oman Medical Journal, vol. 28, no. 4, pp. 260-263, 2013.

[24] A. M. Al-Hakami, "Pattern of thyroid, celiac, and anti-cyclic citrullinated peptide autoantibodies coexistence with type 1 diabetes mellitus in patients from southwestern Saudi Arabia," Saudi Medical Journal, vol. 37, no. 4, pp. 386-391, 2016.

[25] A. S. Al-Ajlan, "Screening of coeliac disease in undetected adults and patients diagnosed with irritable bowel syndrome in Riyadh, Saudi Arabia," Saudi Journal Of Biological Sciences, vol. 23, no. 4, pp. 462-466, 2016.

[26] A. M. Al-Hakami, "Seroprevalence of coeliac disease in at-risk subjects at the main tertiary hospital, southwest of Saudi Arabia," Arab Journal of Gastroenterology, vol. 17, no. 1, pp. 4144, 2016.

[27] A. A. Mansour and A. A. Najeeb, "Coeliac disease in Iraqi type 1 diabetic patients," Arab Journal of Gastroenterology, vol. 12, no. 2, pp. 103-105, 2011.

[28] J. Fraser, N. J. Woodhouse, O. El-Shafie, S. Al-Kindy, and P. Ciclitira, "Occult celiac disease in adult Omanis with unexplained iron deficiency anemia," Saudi Medical Journal, vol. 24, no. 7, p. 791, 2003.

[29] I. Oujamaa, M. Sebbani, L. Elmoumou et al., "The prevalence of celiac disease-specific auto-antibodies in type 1 diabetes in a Moroccan population," International Journal of Endocrinology, vol. 2019, Article ID 7895207, 9 pages, 2019.

[30] F. Alyafei, A. Soliman, F. Alkhalaf et al., "Prevalence of $\beta$-cell antibodies and associated autoimmune diseases in children and adolescents with type 1 diabetes (T1DM) versus type 2 diabetes (T2DM) in Qatar," Acta bio-medica: Atenei Parmensis, vol. 89, Supplement 5, p. 32, 2018.

[31] R. Odeh, A. Alassaf, L. Gharaibeh, S. Ibrahim, F. Khdair, and K. Ajlouni, "Prevalence of celiac disease and celiac-related antibody status in pediatric patients with type 1 diabetes in Jordan," Endocrine Connections, vol. 8, no. 6, pp. 780-787, 2019.

[32] F. AlRuwaily, H. A. Kattan, A. M. AlMehaidib, and W. AlDekhail, "Prevalence of celiac disease in Saudi children with Down syndrome: a retrospective study," International
Journal of Pediatrics and Adolescent Medicine, vol. 4, no. 2, pp. 51-53, 2017.

[33] R. A. Alghamdi, A. H. Alghamdi, and A. A. Fureeh, "Seroprevalence of celiac disease among symptom-free type 1 diabetes mellitus in Al-Baha region, Saudi Arabia," Journal of Pharmacy and Biological Sciences, vol. 13, pp. 22-26, 2018.

[34] M. Alshareef, K. Aljabri, S. Bokhari, A. Al Jiffri, H. Abu Elsaoud, and A. Akl, "The prevalence of celiac disease in Saudi patients with type 1 diabetes mellitus: cross sectional study," International Journal of Diabetes Metabolic Disorders, vol. 1, no. 1, pp. 1-4, 2016.

[35] A. Al-Agha, M. Alafif, and I. Abd-Elhameed, "Glycemic control, complications, and associated autoimmune diseases in children and adolescents with type 1 diabetes in Jeddah, Saudi Arabia," Saudi Medical Journal, vol. 36, no. 1, pp. 26-31, 2015.

[36] Y. Abdulrazzaq, T. I. El-Azzabi, S. M. Al Hamad, S. Attia, A. Deeb, and E. H. Aburawi, "Occurrence of hypothyroidism, diabetes mellitus, and celiac disease in Emirati children with Down's syndrome," Oman Medical Journal, vol. 33, no. 5, pp. 387-392, 2018.

[37] M. B. Hariz, M. Kallel-Sellami, L. Kallel et al., "Prevalence of celiac disease in Tunisia: mass-screening study in schoolchildren," European Journal Of Gastroenterology \& Hepatology, vol. 19, no. 8, pp. 687-694, 2007.

[38] Y. M. Khayyat, "Serologic markers of gluten sensitivity in a healthy population from the western region of Saudi Arabia," Saudi Journal of Gastroenterology, vol. 18, no. 1, pp. 23-25, 2012.

[39] A. M. Aljebreen, M. A. Almadi, A. Alhammad, and F. Z. Al Faleh, "Seroprevalence of celiac disease among healthy adolescents in Saudi Arabia," World Journal of Gastroenterology, vol. 19, no. 15, pp. 2374-2378, 2013.

[40] M. M. Al Hatlani, "Prevalence of celiac disease among symptom-free children from the Eastern Province of Saudi Arabia," Saudi Journal of Gastroenterology, vol. 21, no. 6, pp. 367-371, 2015.

[41] M. Abu-Zekry, D. Kryszak, M. Diab, C. Catassi, and A. Fasano, "Prevalence of celiac disease in Egyptian children disputes the east-west agriculture-dependent spread of the disease," Journal of Pediatric Gastroenterology and Nutrition, vol. 47, no. 2, pp. 136-140, 2008.

[42] A. Mankai, H. Landolsi, A. Chahed et al., "Celiac disease in Tunisia: serological screening in healthy blood donors," Pathologie Biologie, vol. 54, no. 1, pp. 10-13, 2006.

[43] Y. A. Abu-Zeid, W. S. Jasem, B. Lebwohl, P. H. Green, and G. ElGhazali, "Seroprevalence of celiac disease among United Arab Emirates healthy adult nationals: a gender disparity," World Journal of Gastroenterology, vol. 20, no. 42, pp. 15830-15836, 2014.

[44] E. B. Wafa'a Al-Qabandi, D. Al-Abdulrazzaq, K. Hamadi, and R. F. Al, "Celiac disease in children: is it a problem in Kuwait?," Clinical and Experimental Gastroenterology, vol. 8, p. 43, 2015.

[45] O. I. Saadah, "Celiac disease in children and adolescents at a singe center in Saudi Arabia," Annals of Saudi Medicine, vol. 31, no. 1, pp. 51-57, 2011.

[46] A. Al Sarkhy, M. I. El Mouzan, E. Saeed et al., "Clinical characteristics of celiac disease and dietary adherence to gluten-free diet among Saudi children," Pediatric Gastroenterology, Hepatology \& Nutrition, vol. 18, no. 1, pp. 23-29, 2015.

[47] A. Saeed, A. Assiri, H. Assiri, A. Ullah, and M. Rashid, "Celiac disease in Saudi children: evaluation of clinical features and 
diagnosis," Saudi Medical Journal, vol. 38, no. 9, pp. 895-899, 2017.

[48] E. Lionetti, S. Gatti, A. Pulvirenti, and C. Catassi, "Celiac disease from a global perspective," Best Practice \& Research Clinical Gastroenterology, vol. 29, no. 3, pp. 365-379, 2015.

[49] E. Lionetti and C. Catassi, "New clues in celiac disease epidemiology, pathogenesis, clinical manifestations, and treatment," International Reviews of Immunology, vol. 30, no. 4, pp. 219231, 2011.

[50] K. Mustalahti, C. Catassi, A. Reunanen et al., "The prevalence of celiac disease in Europe: results of a centralized, international mass screening project," Annals of Medicine, vol. 42, no. 8, pp. 587-595, 2010.

[51] A. K. Carlsson, I. E. Axelsson, S. K. Borulf, A. C. Bredberg, and S.-A. Ivarsson, "Serological screening for celiac disease in healthy 2.5-year-old children in Sweden," Pediatrics, vol. 107, no. 1, pp. 42-45, 2001.

[52] A. Tommasini, T. Not, V. Kiren et al., "Mass screening for coeliac disease using antihuman transglutaminase antibody assay," Archives of Disease in Childhood, vol. 89, no. 6, pp. 512-515, 2004.

[53] C. J. Hovell, J. A. Collett, G. Vautier et al., "High prevalence of coeliac disease in a population-based study from Western Australia: a case for screening?," Medical Journal of Australia, vol. 175, no. 5, pp. 247-250, 2001.

[54] C. J. Hovell, J. A. Collett, G. Vautier et al., "Prevalence of celiac disease in Argentina: screening of an adult population in the La Plata area," The American Journal of Gastroenterology, vol. 96, no. 9, pp. 2700-2704, 2001.

[55] R. P. Oliveira, V. L. Sdepanian, J. A. Barreto et al., "High prevalence of celiac disease in Brazilian blood donor volunteers based on screening by IgA antitissue transglutaminase antibody," European Journal of Gastroenterology \& Hepatology, vol. 19, no. 1, pp. 43-49, 2007.

[56] H. B. Cook, M. J. Burt, J. A. Collett, M. R. Whitehead, C. M. Frampton, and B. A. Chapman, "Adult coeliac disease: prevalence and clinical significance," Journal of Gastroenterology and Hepatology, vol. 15, no. 9, pp. 1032-1036, 2001.

[57] D. Bai, P. Brar, S. Holleran, R. Ramakrishnan, and P. H. Green, "Effect of gender on the manifestations of celiac disease: evidence for greater malabsorption in men," Scandinavian Journal of Gastroenterology, vol. 40, no. 2, pp. 183-187, 2009.

[58] C. Ciacci, M. Cirillo, G. Giorgetti et al., "Low plasma cholesterol: a correlate of nondiagnosed celiac disease in adults with hypochromic anemia," The American Journal of Gastroenterology, vol. 94, no. 7, pp. 1888-1891, 1999.

[59] S. Guandalini and A. Assiri, "Celiac disease: a review," JAMA Pediatrics, vol. 168, no. 3, pp. 272-278, 2014.

[60] S. D. Rampertab, N. Pooran, P. Brar, P. Singh, and P. H. Green, "Trends in the presentation of celiac disease," The American Journal of Medicine, vol. 119, no. 4, pp. 355.e9-355.e14, 2006.

[61] A. Lerner, P. Jeremias, and T. Matthias, "Gut-thyroid axis and celiac disease," Endocrine Connections, vol. 6, no. 4, pp. R52R58, 2017.

[62] M. El-Salhy, J. G. Hatlebakk, O. H. Gilja, and T. Hausken, “The relation between celiac disease, nonceliac gluten sensitivity and irritable bowel syndrome," Nutrition Journal, vol. 14, no. 1, p. 92, 2015.
[63] T. Amiriani, S. Besharat, G. Roshandel, and A. Shalizar, "Should we look for celiac disease in irritable bowel syndrome?," Oman Medical Journal, vol. 26, no. 1, pp. 59-60, 2011.

[64] A. Rubio-Tapia, J. F. Ludvigsson, T. L. Brantner, J. A. Murray, and J. E. Everhart, "The prevalence of celiac disease in the United States," The American Journal Of Gastroenterology, vol. 107, no. 10, pp. 1538-1544, 2012. 